\title{
Use of an allogenous tunica vaginalis conserved in $98 \%$ glycerine for keratoplasty in dogs
}

\section{Emprego da túnica vaginal alógena, conservada em glicerina a $98 \%$, na ceratoplastia em cães}

\author{
Felipe Antônio Mendes Vicenti, ${ }^{*}$ José Luiz Laus, ${ }^{*}$ João Moreira da Costa Neto, ${ }^{* *}$ Ivia Carmen Taglieri, ${ }^{*}$ \\ Carla de Freitas Campos, ${ }^{*}$ Adriana Torrecilhas Jorge, ${ }^{\star}$ Affonso Luiz Ferreira, ${ }^{\star \star \star}$ Alexandra Pinheiro Fantinatti *
}

\begin{abstract}
We evaluated the use of an allogenous tunica vaginalis conserved in $98 \%$ glycerine for lamellar keratoplasty in dogs. Seven dogs were submitted to keratoplasty and clinically evaluated during the initial ( 1 to 15 days), intermediate (16 to 30 days) and late (31 to 120 days) postoperative periods. The corneas were evaluated by light microscopy at 1, 3, 7, 15, 30,60 and 120 days after surgery. Photophobia, epiphora, blepharospasm, corneal edema, ocular secretion and chemosis were observed during the initial periods, and tended to disappear during the intermediate periods. Vascular neoformation started around the 4th day, with a maximum intensity on the 25th day and a gradual regression thereafter, and tended to disappear between the 60th and 120th day. The graft itself and adjacent areas showed a tendency towards the reestablishment of transparency during the late postoperative periods. With respect to morphology, an inflammatory infiltrate characterized by the invasion of polymorphonuclear and mononuclear leukocytes was observed which disappeared by the 60th postoperative day, when the graft was found to be incorporated and the stroma returned to normal. The present results led us to conclude that the allogenous tunica vaginalis conserved in $98 \%$ glycerine was feasible and efficient for lamellar keratoplasty in dogs.
\end{abstract}

Keywords: cornea, keratoplasty, tunica vaginalis, allogenous graft, dogs.

\section{Resumo}

Avaliou-se a túnica vaginal alógena, conservada em glicerina a $98 \%$, na ceratoplastia lamelar em cães. Sete cães foram submetidos à ceratoplastia e avaliados clinicamente em períodos iniciais ( 1 a 15 dias), intermediários (16 a 30 dias) e tardios (31 a 120 dias) de pós-operatório. As córneas foram avaliadas em microscopia de luz aos um, três, sete, 15, 30, 60 e 120 dias de pós-operatório. Fotofobia, epífora, blefarospasmo, edema corneano, secreção ocular e quemose foram observados nos períodos iniciais, tendendo a desaparecerem nos períodos intermediários. Neoformação vascular iniciou-se próximo aos dos quatro dias, apresentando intensidade máxima aos 25 dias de pós-operatório, quando iniciou regressão gradativa para tender à ausência entre 60 e 120 dias. Nas áreas próprias e adjacentes aos enxertos houve tendência ao reestabelecimento da transparência nos períodos tardios de pós-operatório. Quanto à morfologia, o infiltrado inflamatório caracterizou-se pela invasão de leucócitos polimorfonucleares e mononucleares, tendendo à ausência aos 60 dias de pós-operatório, quando notou-se que o enxerto foi incorporado e o estroma tendeu à normalidade. Os resultados obtidos com a pesquisa permitem admitir que a túnica vaginal alógena, conservada em glicerina a $98 \%$, mostrou-se factível e eficaz na ceratoplastia lamelar em cães.

Palavras-chave: córnea, ceratoplastia, túnica vaginal, enxerto alógeno, cães.

\section{Introduction}

Among the lesions affecting the cornea, ulcers, abrasions, lacerations and perforations characterized by the loss of epithelium and of variable portions of the stroma have been emphasized (Startup, 1984). Particularly outstanding among these disorders is ulcerative keratitis (Vaughan, Asbury, 1977;
Startup, 1984) whose treatment is based on the relief of clinical signs, as well as on prophylaxis for descemetoceles and complete perforations (Startup, 1984; Nasisse, 1985; Helper, 1989; Kern 1990; Slatter, 1990). Covering with a third eyelid (Barnet, 1966; Startup, 1984; Helper, 1989; Slatter, 1990) and tarsorrhaphy (Nasisse, 1985; Helper, 1989; Portnoy et al., 1989;

\footnotetext{
* Faculdade de Ciências Agrárias e Veterinárias - FCAV, UNESP, Departamento de Clínica e Cirurgia Veterinárias, Serviço de Oftalmologia, Via de Acesso Prof. Paulo Donato Castellane, s/nº, Jaboticabal, SP, Brazil, CEP: 14884-900. Author for correspondence: José Luiz Laus, email: jllaus@fcav.unesp.br

** Universidade Federal da Paraíba, UFPB, Patos, PB, Brazil.

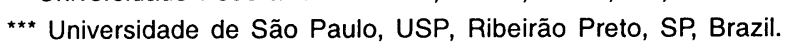


Kern, 1990) have been used for the conservative treatment of superficial corneal lesions. However, due to their severity, profound and descemetocele corneal ulcers require specific therapy in order to prevent perforations (Slatter, 1990).

Among corneal surgeries, partial or total conjunctival grafts have been studied by Gundersen (1958), Startup (1984), Nasisse (1985), Portnoy et al. (1989), Kern (1990), Slatter (1990). Pediculate grafts have been evaluated by Startup (1984), Kern (1990), Slatter (1990), Morales et al.(1996), Laus et al.(1996), and free grafts by Thoft(1977), Thoft (1982), Startup (1984), Nasisse (1985), Peiffer Jr. et al. (1987), Portnoy et al. (1989), Barros (1990), Kern (1990), Slatter (1990), Hacker (1991), Souza (1994), Garcia et al. (1996), Laus et al. (1996), Morales et al. (1996), Andrade et al. (1999) and Galera (1999).

With respect to the origin of the implants used, autogenous (Panchbhai, Kulkarni, 1986; Galera et al.,1999), allogenous (Lugo, Arentsen, 1987; Panchbhai, Kulkarni, 1987; Naumann, Sautter, 1988; Garcia et al., 1996; Hansen, Guandalini, 1999), and xenologous grafts (Panchbhai, Kulkarni, 1987; Naumann, Sautter, 1988; Guimarães, 1979; Barros et al., 1990; Laus, 1994; Andrade et al., 1999) have been studied regarding the superiority of one graft type over the other with contradictory results. Alternative biological materials used for keratoplasty in dogs with good results are equine pericardium (Barros et al., 1990) and amniotic membrane (Barros et al., 1999), sardine scales (Sardinela brasiliensis) (Laus, 1994), allogenous peritoneum (Garcia et al., 1996), equine renal capsule (Andrade et al., 1999), and fresh autogenous tunica vaginalis (Galera et al., 1999).

Direct corneal sutures (Peiffer Jr. et al., 1987; Helper, 1989; Kern,1990; Gilger, Whitley, 1999), corneal-scleral (Parshall, 1973; Powel, 1986; Peiffer Jr. et al., 1987; Slatter, 1990; Gilger, Whitley, 1999) and corneal-conjunctival transpositions (Kern, 1990), adhesive substances (Webster et al., 1968; Peruccio, 1983; Wendler et al., 1983; Portnoy et al., 1989; Laus et al., 1993), contact lenses (Nasisse, 1985; Hermann, 1989; Helper, 1989; Friedberg et al., 1991) and Biofil ${ }^{\circledR}$ cellulose films (Pippi, Sampaio, 1990) have been studied and occasionally proposed as treatment for corneal lesions.

\section{Material and methods}

This study was in accordance with the Association for Research in Vision and Ophthalmology (ARVO) statement for the use of animals in ophthalmic and vision research.

Seven adult mongrel dogs of both sexes with a mean weight of $10 \mathrm{~kg}$ and considered clinically and ophthalmologically healthy were used. Ophthalmic conditions were evaluated by routine ophthalmic semiology including Schirmer's tear test, biomicroscopy with a slit lamp, indirect binocular ophthalmoscopy, applanation tonometry and the fluorescein test. The animals were then submitted to lamellar keratoplasty using tunica vaginalis conserved in $98 \%$ glycerine as allogenous graft and the corneas were evaluated microscopically in one animal each at $1,3,7,15,30,60$ and 120 days after surgery.

The tunica vaginalis was obtained at the Veterinary Hospital Governador Laudo Natel from adult mongrel animals with irreversible lesions of the spinal marrow or with other noninfectious lesions which required the indication of euthanasia. The parietal portion of the tunica vaginalis of the scrotum was used after dissecting out the portion of the funiculus and the insertion area of the cremaster muscle and adjacent connective tissue. After collection, the material was washed in sterile saline solution and kept in flasks containing $98 \%$ glycerine in aqueous solution at room temperature for a minimum of 30 days before use (Pigossi, 1967).

The left eye of each animal was submitted to keratoplasty. Microsurgical maneuvers were performed under light microscopy ${ }^{1}$ at 6 times magnification. A 5-mm trephine applied to the upper quadrant of the cornea produced partial trephining of the recipient cornea, comprising the epithelium and approximately half the stroma which would receive the tunica vaginalis. The tunica vaginalis was removed from the conservation medium, washed and maintained in sterile $0.9 \%$ saline solution for $10 \mathrm{~min}$, and cut into the appropriate size relative to the recipient area. The graft was fixed with simple interrupted, not totally penetrating, 9-0 monofilament nylon sutures ${ }^{2}$, threaded through a triangular needle, each $1 \mathrm{~mm}$ apart. Four cardinal sustaining sutures were applied, followed by sutures necessary to fix the membrane in the visceral plane on the recipient bed. The corneas were systematically irrigated with $0.9 \%$ sterile saline solution throughout the surgical maneuvers.

After surgery the animals were treated topically with chlorphenicol ophthalmic ointment ${ }^{3}$ at 12-h intervals for 10 days, to prevent bacterial infection. To avoid self-mutilation, the animals received an Elizabethan type collar.

The animals were clinically evaluated every $24 \mathrm{~h}$ and features such as the general condition of the animal, photophobia, epiphora, blepharospasm, ocular secretion (presence or absence, and when present, type classification), chemosis, conjunctival congestion and hyperemia, corneal edema, neovascularization (type and depth), transparency, pigmentation and reflex uveitis were evaluated qualitatively and quantitatively. The parameters adopted for all variables were subjectively classified into: $(-)$ : none, $(+)$ : discrete, $(++)$ : moderate, and $(+++)$ : intense.

The corneas were evaluated by light microscopy in one animal each at 1,3, 7, 15, 30, 60 and 120 days after surgery. The eyeballs that had received the graft were enucleated, fixed in Bouin solution for $24 \mathrm{~h}$ and then kept in $70 \%$ alcohol. In a second step, these preparations were reduced, embedded in paraffin, sagittally cut into $5-\mu \mathrm{m}$ thick sections, and stained with hematoxylin and eosin (HE). The dogs were not euthanised.

\section{Results}

No systemic alterations and no dehiscence, infection or other manifestations at the graft site indicating surgical failure were observed. Photophobia, epiphora, blepharospasm, corneal edema, ocular secretion and chemosis were observed during the initial periods, but tended to disappear during the intermediate periods (Table 1)

Vascular neoformation started by about the 4 th postoperative day, gradually evolved until the 25th day when it was found to be intense (+++), and then regressed until disappearing between 60 and 120 days (Figure 1). 
Table 1 - Clinical evaluation of the corneas of dogs receiving allogenous tunica vaginalis conserved in $98 \%$ glycerine according to qualitative and quantitative criteria.

\begin{tabular}{lccccccc}
\multicolumn{1}{c}{ PARÂMETER } & \multicolumn{7}{c}{ DAYS AFTER SURGERY } \\
Photophobia & 1 & 3 & 7 & 15 & 30 & 60 & 120 \\
Epiphora & ++ & + & + & + & - & - & - \\
Blepharospasm & $+l++$ & $+1++$ & $+1++$ & - & - & - & - \\
Edema & $+l++$ & $+1++$ & $+1++$ & - & - & - & - \\
Secretion & - & + & + & ++ & + & - & - \\
Chemosis & + & + & + & + & - & - & - \\
Neovascularizaton & ++ & ++ & ++ & $++/+$ & + & - & - \\
& - & - & + & +++ & ++ & + & $+1-$
\end{tabular}
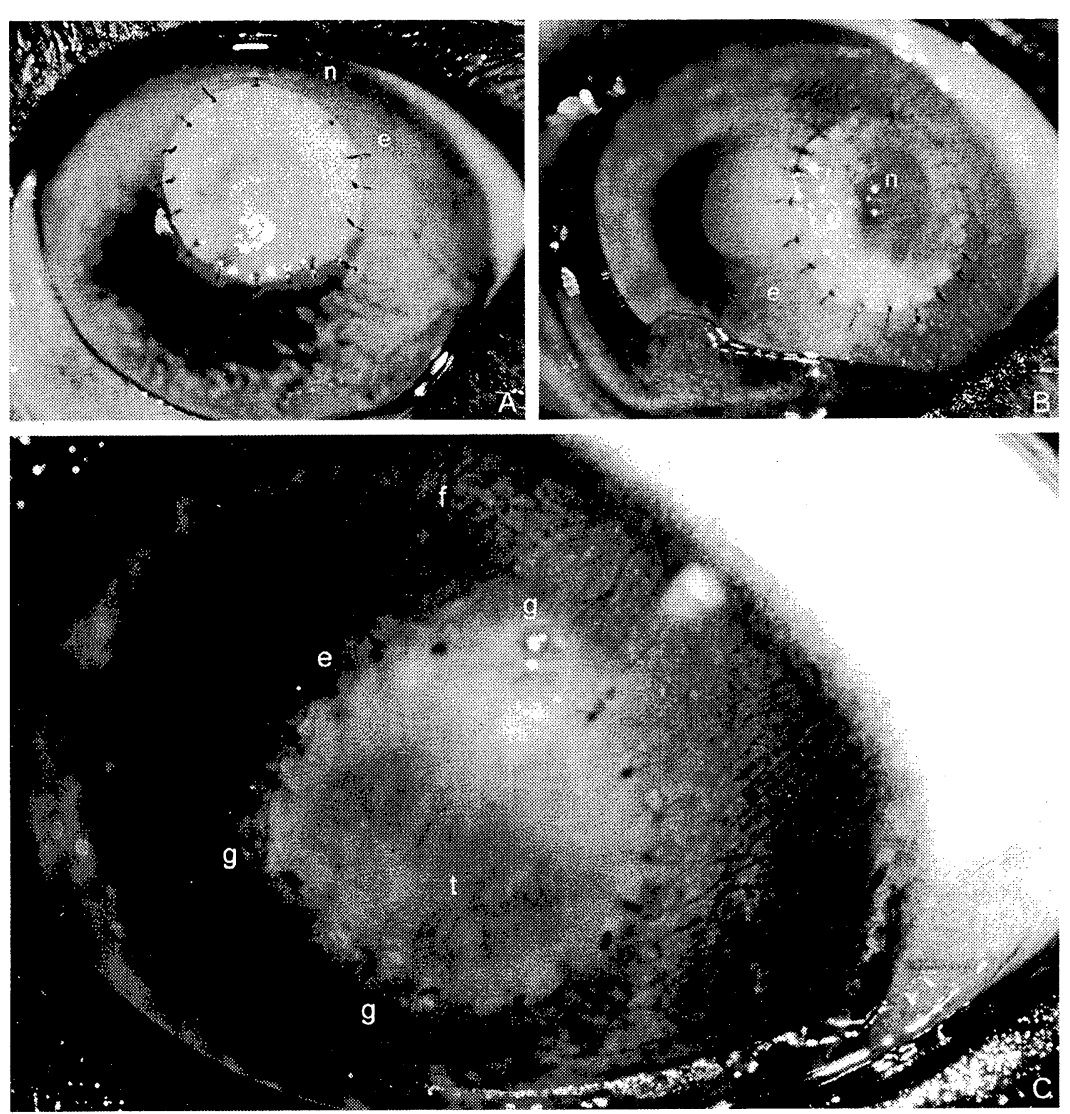

Figure 1 - Photographic images of lamellar keratoplasties using allogenous tunica vaginalis conserved in $98 \%$ glycerine. In $A$, at 7 days after surgery, edema (e) and discrete neovascularization $(n)$ are observed. In $B$, at 15 days after surgery, moderate edema (e) and intense neovascularization (n) are noted. In C, at q20 days after surgery, the suture stitches and the graft area showing a tendency towards transparency $(t)$ are shown. Also, note the clouding (e) surrounding the graft, the ghost vessels $(f)$ in between and some stitch granulomas $(\mathrm{g})$.

The corneas were transparent in the areas close to and distant from the graft. In the graft area itself, edema, neovascularization and a tendency towards the reestablishment of transparency were mainly observed during the late postoperative periods (Figure 1). Moderate pigmentation was found in two animals.

The fluorescein test revealed positive animals until the 4th postoperative day. Reflex uveitis was discrete $(+)$ during the initial periods (1-7 days), with a tendency towards remission from the 8th postoperative day on.
With respect to corneal morphology, an inflammatory infiltrate characterized by invasion with polymorphonuclear and mononuclear leukocytes was observed (Figure 2), with a predominance of polymorphonuclear cells during the initial periods. These cells gradually regressed and were followed by progressive migration of mononuclear cells, a finding which was most evident after 15 days, became discrete after 30 days, and tended to disappear after 60 days.

Corneal edema was found to be discrete during the first three days, moderate from day 7 to 15 , with subsequent regression, and was absent at 30 days after surgery.

Proliferation of basal cells in close contact with the graft and their migration in the basal and apical direction were observed after the first postoperative day. These cells proliferated, differentiated and formed new corneal epithelium covering the graft as early as 7 days after surgery. Reconstituted epithelium - moderately organized and covering the graft - and stroma with a structure similar to amorphous substance, albeit not organized, were also observed by the 7 th postoperative day (Figure 2A).

At 15 days, the epithelium was found to be renewed, stratified and of good thickness, although still disorganized. The stroma was characterized by a large amount of fibroblasts and collagen matrix, as well as a mononuclear cell infiltrate (Figure 2B). At 30 days, organized epithelium with better stratification, and nonfibrillar stromal areas were observed (Figure 2C).

At 60 days, the epithelium presented normal maturation with completely reconstituted corneal layers. In addition, a discrete amount of collagen matrix and rare vessels were observed in the stroma.

Vascular neoformation, evident at 7 days, was discrete and became intense after 15 days. Blood vessels were found to be tortuous and interconnected, and dilated, congested and swollen with red blood cells. They then tended to disappear thereafter, although some were still observed up to 120 days (Figure 2C,D).

The implant was still being incorporated by the 30th day, still showing a small amorphous area. At 60 and 120 days after surgery, the graft had been incorporated and the stroma was normal, showing the characteristic fiber arrangement (Figure 2D).

\section{Discussion}

Keratoplasties per se are the main weapon against the complications, especially morbidity, caused by ulcerative keratitis (Gilger, Whitley, 1999). Lamellar keratoplasties, as used in the present investigation, have been studied by Thoft (1977), Guimarães (1979), Thoft (1982), Startup (1984), Nasisse (1985), Panchbhai, Kulkarni (1986), Panchbhai; Kulkarni (1987), Lugo, Arentsen (1987), Peiffer Jr et al. (1987), Naumann, Sautter (1988), Portnoy et al. (1989), Kern (1990), Slatter (1990), Barros et al. (1990), Hacker (1991), Souza, (1994), Garcia et al. (1996), Laus et al. (1996), Morales 

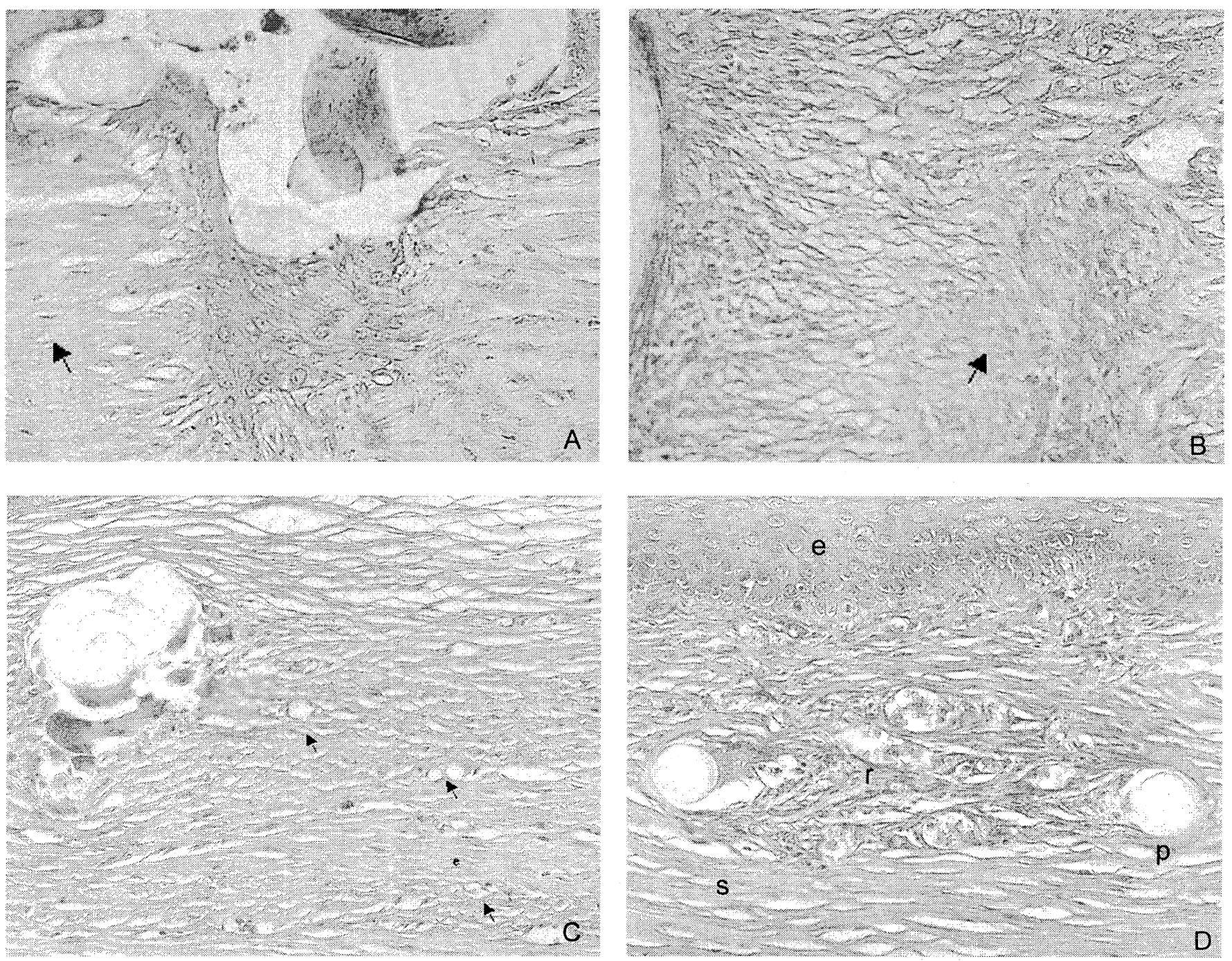

Figure 2 - Photomicrograph of lamellar keratoplasty using allogenous tunica vaginalis conserved in $98 \%$ glycerine. In A, at 7 days after surgery, the stroma with a structure similar to amorphous substance, albeit not organized, can be observed (arrow) (HE, 100X). In B, at 15 days after surgery, the stroma is still disorganized (arrow) (HE, 200X). In C, at 30 days after surgery, newly formed vessels (arrows) and areas of non-fibrillar stroma (e) are observed $(\mathrm{HE}, 300 \mathrm{X})$. In $\mathrm{D}$, at 120 days after surgery, the suture stitches $(\mathrm{p})$ serving as a reference indicating one end of the graft, stroma (s), epithelium (e) evolving to normal and tissue reaction ( $r$ ) due to the suture material can be noted (HE, 200X).

et al. (1996), Barros et al. (1999), Andrade et al. (1999), Galera et al. (1999) e Laus et al., (1999).

In the present study, the parietal portion of the allogenous tunica vaginalis was used based on the study by Galera et al. (1999), who proposed that the parietal surface better adapts to the recipient bed. We also evaluated the tunica vaginalis, its elasticity and ease of isolation.

The material was conserved in $98 \%$ glycerine due to its simple handling, low cost and the good results reported by Pigossi in 1967. In addition, a series of other ophthalmologic studies published by Barros et al. (1990) and subsequently by others have shown the quality of glycerine as a conservation medium.

The usefulness of glycerine as a conservation medium due to its properties regarding the attenuation of tissue antigenicity has been demonstrated (Pigossi, 1967; Lantzman, 1986; Daleck et al., 1988; Pessoa de Barros et al., 1990; Holzchuh et al., 1990; Fuen-tesReyes, 1998).
Photophobia, epiphora, blepharospasm, ocular secretion and chemosis were evident during the initial postoperative periods, with a similar condition having been observed by Souza et al. (1994), Morales et al. (1996), Andrade et al. (1999) e Galera et al (1999). These are frequent findings resulting from the stimulation of the nociceptive endings of the cornea and palpebral conjunctiva (Waring, 1984) and are also due to reflex uveitis which was observed during the first week after surgery (Kern, 1990). It should be pointed out that in the present study the sutures caused discomfort since we decided not to bury them.

The secretion observed in all animals during the initial postoperative period ranged from seromucosal to mucosal and resulted from the stimulus of conjunctival calciferous cells, as also reported by Goncalves (1975).

Conjunctival congestion and hyperemia, more intensely manifested during the initial periods, were due to surgical 
trauma as well as reflex uveitis (Stades et al., 1998). Edema was observed in the graft itself and in the surrounding areas. Barros et al. (1999), Laus et al. (1999) and Galera et al. (1999) observed edema of the same intensity and with the same form of presentation. Edema was evident as early as on the 3 rd postoperative day, tended to regress from the 15th day on, and was no longer observed after 30 days.

Evolution of the corneas followed classical patterns of wound healing, as described by Dempster (1959) and Kudva, Deshpande (1983). Barros et al. (1990), Garcia et al. (1996); Laus et al. (1996), Morales et al. (1996), Barros et al. (1999), Andrade et al. (1999), Galera et al. (1999) reported analogous results.

Grafts and recipient corneas showed a tendency towards transparency during the late postoperative periods, indicating that the implanted material was progressively incorporated. The corneas were found to be transparent in the areas close to and distant from the graft. However, edema and neovascularization were observed in the graft area, which were progressively replaced by scar and ghost vessels during the intermediate and late periods. Similar pictures have been demonstrated by Panchbhai, Kulkarni (1987), Barros et al. (1990), Slatter (1990), Laus et al. (1996), Morales et al. (1996), Andrade et al. (1999), Galera et al. (1999).

Pigmentation was only observed in two animals and was caused by the migration of lymphoid and peripheral melanocytes typical of chronic processes, confirming the findings of Whitley, Gilger (1999), Scagliotti (1988), Slatter (1990) and Tsai et al. (1990).
Light microscopy showed the classical patterns of inflammation and wound healing. Polymorphonuclear and mononuclear cells participated in the processes of phagocytosis and cell debridement. Nasisse (1985) and Kern (1990) described the migration of polymorphonuclear cells along the precorneal layer as early as during the first hours after injury. Migration of mononuclear cells associated with the formation of new vessels was observed in parallel. Macrophages/histiocytes are involved in the phagocytosis of cell debris (Kern, 1990), concomitantly with the proliferation of the collagen matrix deposited by fibroblasts or keratocytes (Slatter, 1990).

Corneal reepithelization was observed by the 7th postoperative day, followed by the epithelial maturation, stratification and organization. Corneal neovascularization followed classical patterns of angiogenesis, as described by Maurice et al. (1966) and cited by Naumann, Sautter (1988) and Andrade et al. (1999). Strieter et al. (1992) demonstrated the participation of interleukin8 , released by the corneal matrix, in the angiogenesis of vessels directed at the center of the lesion. This phenomenon is probably due to the intrinsic response of the inflammatory process caused by surgical trauma (Cotran et al., 1991).

\section{Conclusions}

The present results led us to conclude that the allogenous tunica vaginalis conserved in $98 \%$ glycerine is feasible and efficient for experimental lamellar keratoplasty in dogs, thus representing a new option for the repair of corneal defects.

\section{Acknowledgments}

Research supported by Fundação de Amparo à Pesquisa do Estado de São Paulo - FAPESP (Prócs. no 98/10130-7 and no 98/03153-0).

\section{References}

ANDRADE, A. L., LAUS, J. L., FIGUEIREDO, F., BATISTA, C. M. The use of preserved equine renal capsule to repair lamellar corneal lesions in normal dogs. Vet. Ophthalmol., v. 2, p. 79-82, 1999.

BARNET, K. C. The corneal ulcer. VI Surgical treatment. J. Small Anim. Pract., v. 7, p. 275-277, 1966.

BARROS, P. S. M., SAFATLE, A. M. V., MALERBA, T. A., BURNIER, M. N. Reparação cirúrgica da córnea de cães usando pericárdio de eqüino conservado em glicerina. In: CONGRESSOBRASILEIRODA ANCLIVEPA, 13., 1990, Gramado. Anais... Gramado: ANCLIVEPA, p. 11, 1990.

BARROS, P. S. M., GARCIA, J. A., LAUS, J. L., FERREIRA, A. L., SALES GOMES, T. L. The use of xenologous amniotic membrane to repair canine corneal perforation created by penetrating keratectomy. Vet. Ophthalmol., v. 1, n. 2-3, p. 119-123, 1999.

COTRAN, R. S., ROBBINS, S. L., KUMAR, V. Patologia estruturale funcional. 4. ed. Rio de Janeiro: Guanabara Koogan, 1991. p. 33-72. DALECK, C. R., DALECK, C. L. M., ALESSI, A. C., PADILHA FILHO, J. G., COSTA NETO, J. M. Substituição de um retalho diafragmático de cão por peritônio de bovino conservado em glicerina: estudo experimental. Ars Vet., v. 4, n. 1, p. 53-61, 1988.

DEMPSTER, W. J. Biological spare parts. Vet. Rec. n. 71, p. 320, 1959. ERLICH, M. I., PHINNEY, R. B., MONDINO, B. J. et al. Techniques in lamellar keratoplasty. International Ophthalmology Clinics, v. 28, p. 24-29, 1988.

FRIEDBERG, M. L., PLEYER, U., MONDINO, B. J. Device drug delivery to the eye collagen shields, iontophoresis, and pumps. Ophthalmology, v. 98, n. 5, p. $725-732,1991$.
FUENTES-REYES, E. E. Implante de pericárdio de eqüino preservado em glicerina a $98 \%$ como substituto biológico de segmento de tendão do músculo extensor ulnar do carpo em cães. Estudo experimental. 1998. 89 f. Tese (Doutorado) - Faculdade de Medicina Veterinária e Zootecnia - Universidade de São Paulo.

GALERA, P. D., LAUS, J. L., FERREIRA; A. L. Use of autogenous vaginal membrane testes in lamellar keratoplasty in dogs (Canis familiaris, LINNAEUS, 1758). In: CONGRESS OF THE WORLD SMALL ANIMAL VETERINARY ASSOCIATION, 24, 1999, Lyon. Proceedings... Lyon: W.S.A.V.A., 1999.

GARCIA, J. A., BARROS, P. S. M., LAUS, J. L., FERREIRA, A. L., SAFATLE, A.M. V. Implante de peritônio homólogo conservado após ceratectomia lamelar em cães. Braz. J. Vet. Res. Anim. Sci., v. 3, n. esp., p. 290-294, 1996.

GILGER, B. C., WHITLEY, R. D. Surgery of the cornea and sclera. In: GELATT, K. N. Veterinary Ophthalmology. 3. ed. Philadelphia: Lippincott Williams \& Wilkins, 1999. p. 675-700.

GONÇALVES, C. P. Queratites. In: Brasilia: Atheneu, 1975. p. 131-140. (ed.) Oftalmologia. 4. ed.

GUIMARÃES, R. Q. Ceratoplastia interlamelar xenógena de galinha em coelho; utilizando córneas conservadas em cloreto de sódio por três dias, um mês e 14 anos. Estudo biomicroscópico e histopatológico. 1979. 233 f. Tese (Doutorado) - Faculdade de Medicina - Universidade Federal de Minas Gerais.

GUNDERSEN, T. Conjunctival flaps in the treatment of corneal disease with reference to a new technique of application. Arch. Ophthalmol., v. 60, p. $880-888,1958$. 
HACKER, D. V. Frozen corneal grafts in the dogs and cats: a report on 19 cases. J. Am. Anim. Hosp. Assoc., v. 27, p. 387-398, 1991.

HANSEN, P. A., GUANDALINI, A. A retrospective study of 30 cases of frozen lamellar corneal graft in dogs and cats. Veterinary. Ophthalmology, v. 2, n. 4, p. 233-241, 1999.

HELPER, L. C. Diseases and surgery of the cornea and sclera. In: . Magrane's Canine Ophthalmology. 4. ed. Philadelphia: Lea \& Febiger, 1989. p. 102-149.

HERMANN, K. Terapeutic use of hydrophilic contact lenses. In: KIRK, R. W., BONAGURA, J. D. (ed.). Current Veterinary Therapy: Small Animal Practice. Philadelphia: W.B. Saunders, 1989. v. 9, p. 640-641. HOLZCHUH, M. P., CIPOLA, W. W. V., BORELI, V., FARIAS, E. C., TANAKA, H., MOREIRA, M. A. Sobre o emprego experimental do. pericárdio de eqüino conservado em glicerina, na substituição do tendão de Aquiles em coelhos. Aspectos histológicos. Comun. Cient. Fac. Med. Vet. Zootec. Univ. São Paulo, v. 14, n. 1, p. 57, 1990.

KERN, T. J. Ulcerative keratitis. Vet. Clin. North Am. Small Anim. Pract., v. 20, n. 3, p. 643-666, 1990.

KUDVA, V., DESHPANDE, K. S. Experimental autogenous and homologous lamellar corneal grafting in bovines. Indian Vet. J., v. 60, p. 56-61, 1983.

LANTZMAN, M. Utilização de pericárdio de eqüino conservado em glicerina na reparação cirúrgica do duodeno de cães - estudo experimental. 1986. 60 f. Dissertação (Mestrado) - Faculdade de Medicina Veterinária e Zootecnia - Universidade de São Paulo.

LAUS, J. L. Emprego da escama de sardinha (Sardinella brasiliensis - Steidachner, 1859), conservada em glicerina, como sucedâneo de córneas no reparo de ceratectomias superficiais: Estudo experimental em cães. (Canis familiaris - Linnaeus, 1758). 1994. $71 \mathrm{f}$. Tese (Livre-docência em Medicina Veterinária) - Faculdade de Ciências Agrárias e Veterinárias - Universidade Estadual Paulista.

SOUZA, M. S. B., MORALES, A., ROSSI, A. M., BARROS, P. M. $S$. Avaliação dos efeitos de um novo adesivo para fins biológicos (COLAGEL) na ceratoplastia experimental em cães. In: CONGRESSO BRASILEIRO DA ANCLIVEPA, 15., 1993. Rio de Janeiro. Resumos... Rio de Janeiro: Anclivepa, 1993. p. 72.

LAUS, J. L., SOUZA, M. S. B., MORALES, A., ANDRADE, A. L., FIGUEIREDO, F., SANTOS, J. M., VALERI, V. Comparação entre ceratoplastias lamelares por enxertos autógenos, livres, de córnea e pediculados de conjuntiva. Estudo experimental no cão (Canis familiaris - Linnaeus, 1758). Braz. J. Vet. Res. Anim. Sci., v. 33, n. 1, p. 41-46, 1996.

GALERA, P. D., SCHOCKEN-ITURRINO, R. P., CAVASSANI, M. M., ANDRADE, A. L. Bilateral lamellar keratoplasty in descemetocele treatment in dQg with botulism by use of equine renal capsule and conjunctival pedicle graft. Ciência Rural, v. 29, n. 2, p. 355-359, 1999. LUGO, M., ARENTSEN, J. J. Treatment of neurotrophic ulcer with conjunctival flaps. Am. J. Ophthalmol., v. 103, n. 5, p. 711-712, 1987. MORALES, A., LAUS, J. L., SOUZA, M. S. B., SANTOS, J. M., FIGUEIREDO, F., VALERI, V. Comparação entre enxertos autógenos livres e pediculados de conjuntiva no reparo de ceratectomias superficiais. Estudo experimental no cão (Canis familiaris - Linnaeus, 1758). Braz. J. Vet. Res. Anim. Sci., v. 33, n. 1, p. 28-31, 1996.

NASISSE, M. P. Canine ulcerative keratitis. Comp. Cont. Educ., v. 7, n. 9, p. 686-701, 1985.

NAUMMAN, G. O. H., SAUTTER, H. Surgical procedures on the comea. In: BLODI, F. C., MACKENSEN, G., NEUBAUER, H. Surgical Ophthalmology. 1. ed. Berlin: Springer-Verlag, 1988. p. 434-440.

PANCHBHAI, V. S., KULKARNI, P. E. Corneal transplantation in buffalo calves (Bubalus bubalis) - I. (Autogenous and Homogenous Grafts). Indian Vet. J., v. 63, p. 737-740, 1986.

PANCHBHAI, V. S., KULKARNI, P. E. Penetrating comeal transplantation in Buffalus calves-III (Autogenous, Homogenous and Heterogenous Grafts). Indian Vet. J., v. 64, p. 223-226, 1987.
PARSHALL, C. J. Lamellar corneal-scleral transposition. J. Am. Anim. Assoc., v. 9, p. 270-277, 1973.

PEIFFER Jr., R. L., NASISSE, M. P., COOK, C. S., HARLING, D. E. Surgery of the canine and feline orbit, adnexa and globe. Part 6: Surgery of the cornea. Companion Anim. Pract., v. 1, n. 7, p. 3-13, 1987.

PERUCCIO, C. Diagnosi e trattamento delle lesioni corneali. Sci. Vet., p. 3-8, 1983.

PESSOA DE BARROS, T. E., GUARNIERO, R., CHIH, C. L., CHOI, P.S., RODRIGUES, C. J. Plasty of tendon with dura mater. Arch. Orthop. Trauma Surg., v. 109, p. 131-132, 1990.

PIGOSSI, N. A glicerina na conservação de dura-máter. Estudo experimental. 1967. Tese (Livre-docência) - Faculdade de Medicina - Universidade de São Paulo.

PIPPI, N. L., SAMPAIO, A. S. J. H. Estudos preliminares sobre o comportamento do Biofil na ceratoplastia lamelar em coelhos. In: CONGRESSO BRASILEIRO DA ANCLIVEPA, 13., 1990, Gramado. Resumos...Gramado: ANCLIVEPA, 1990.

PORTNOY, S. L., INSLER, M. S., KAUFMAN, H. E. Surgical management of corneal ulceration and perforation. Surv. Opthalmol., v. 34, n. 1, p. 47-58, 1989.

POWEL, N. G. Cirurgia da córnea. In: BOJRAB, M. J. Cirurgia dos pequenos animais. 2. ed. São Paulo: Roca, 1986. p. 66-71.

SCAGLIOTTI, R. H. Tarsoconjunctival island graft for the treatment of deep corneal ulcers, descemetoceles, and perforations in 35 dogs and 6 cats. Seminars in Veterinary Medicine and Surgery (Small Animal). v. 3, n. 1, p. 69-76, 1988.

SLATTER, D. Comea and sclera. In: Ophthalmology. 2. ed. Philadelphia:

SOUZA, M. S. B. Comparação entre ceratoplastias lamelares por enxertos autólogos de córnea e conjuntiva no reparo de ceratectomias superficiais em cães (Canis familiaris - Linnaeus, 1758): estudo clínico e morfológico. 1994. 67 f. Tese (Mestrado em Cirurgia Veterinária) - Faculdade de Ciências Agrárias e Veterinárias - Universidade Estadual Paulista.

STADES, F. C., WYMAN, M., BOEVÉ, M. H., NEUMANN, W. Ophthalmology for the Veterinary Practioner. Hannover: Schlütersche GmbH \& Co. KG, 1998.

STARTUP, F. C. Corneal ulceration in the dog. J. Small Anim. Pract., v. 25, p. 737-752, 1984.

STRIETER, R. M., KUNKEL, S. L., ELNER, V. M., MARTONYI, C. L., $\mathrm{KOCH}$, A. E., POLVERINI, P. J., ELNER, S. G. Interleukin-8. A corneal factor that induces neovascularization. Am. J. Pathol., Philadelphia, v. 141, n. 6, p. 1.279-1.2\&4, 1992.

THOFT, R. A. Conjunctival transplantation. Arch. Ophthalmol., v. 95, p. 1.425-1.427, 1977.

THOFT, R. A. Indication for cojunctival transplantation. Ophthalmology, v. 89, n. 4 , p. 335-339, 1982.

TSAI, J. F., SUN, T. T., TSENG, S. C. Comparison of limbal and conjunctival autograft transplantation in corneal surface reconstruction in rabbits. Ophthalmology, Hagerstown, v. 97, n. 4, p. 446-455, 1990.

VAUGHAN, D., AUSBURY, T. Córnea e esclerótica. In: _. . Oftalmologia Geral. São Paulo: Universidade de São Paulo, 1977, p. 71-87. WARING, G. O Corneal structure and pathophysiology. In: LEIBOWITZ, $\mathrm{H}$. Corneal Disorders: Clinical Diagnosis and Management. Philadelphia: W.B. Saunders, 1984. p. 3-25.

WEBSTER, R. G., SLANSKY, H. H., REFOJO, M. F., BORUCHOFF, S. A., DOHLMAN, C. $H$. The use of adhesive for the closure of corneal perforations. Arch. Ophthalmol., v. 80, n. 6, p. 705-709, 1968.

WENDLER, M. E., LICHTENBERG, W., FALZONI, W. L., FALZONI, R., BELFORD Jr., R. Adesivos teciduais no tratamento da perfuração corneana. Estudo comparativo em cobaios. Arcq. Bras. Oftalmol., v. 46, n. 5, p. 138-140, 1983.

WHITLEY, R. D., GILGER, B. C. Diseases of the canine cornea and sclera. In: GELATT, K. N. Veterinary Ophthalmology. 3. ed. Philadelphia: Lippincott Williams \& Wilkins, 1999. p. 635-674. 